\title{
Relationship of Foreign Trade and Economic Growth in Eurasian Economy: Panel Data Analysis
}

\author{
Nazife Özge Kılıç ${ }^{1} \&$ Murat Beser ${ }^{2}$ \\ ${ }^{1}$ Department of Economics, Agri Ibrahim Cecen University, Agri, Turkey \\ Correspondence: Nazife Özge Kılıç, Department of Economics, Agri Ibrahim Cecen University, Agri, Turkey.
}

Received: June 18, 2017

Accepted: July 1, 2017

Online Published: July 20, 2017

doi:10.5539/ijef.v9n9p1

URL: https://doi.org/10.5539/ijef.v9n9p1

\begin{abstract}
In this study, relationship between foreign trade and economic growth had been examined for the countries of Eurasia Economic Union by using data in era of 1992-2015 with the help of panel data analysis. First of all, cross-sectional dependency and homogeneity test had been done in the study and it had been concluded that there is cross-sectional dependency in between the series. For this purpose, unit root and causality test considering the cross-sectional dependency had been applied. Relationship between the variables had been analyzed with the panel causality test developed by Konya (2006). It had been determined that there is bi-directional causality from growth to export and unidirectional causality from growth to import.
\end{abstract}

Keywords: import, export, panel bootstrap causality test, Eurasian Economic Union, economic growth

\section{Introduction}

A country has to be involved in activities like import and export to be economic contact with another country. Capital shortage and saving gap that arise because of the insufficient income level in the underdeveloped or developing countries have interrupted the growth and development processes. Because of this, interaction between import and export that means foreign trade have taken complicated aspects and mutual cause and effect relations may be seen. Underdeveloped countries may ensure their economic development by importing their industrial and investment goods in exchange for income that they had gained from export. Since financing of development investments depend on the income obtained from the import, import incomes should be increased for acceleration of development.

Relationship between economic growth and foreign trade have been based on two approaches. One of them is growth hypothesis based on import and other one is growth hypothesis based on export. In the growth hypothesis based on import, it has been thought that import affects the economic growth positively in a roundabout way. At the end of the import, resources are going to be shifted from nonoperative nontraded sectors to import sector and efficient usage of resources is going to cause productivity growth and economic growth. At the end of the import, research and development are going to increase productivity by enabling to learn by doing and improve skill by following the modern technologies and it is going to cause to economic growth in conclusion (Grosman \& Helpman, 1991). In the hypothesis based on export, more capital and intermediate goods have been exported due to increase of production capacity of country as parallel to economic growth and increase in need of input so export has started to increase (Tunçsiper \& Rençber, 2017).

The purpose of this study is analyzing the relationship between foreign trade and economic growth in Eurasia Economic Union countries by panel causality method in the era 1992-2015. Annual data between 1992-2015 had been used for the analysis. Study has consisted of three chapters by this purpose. In the first chapter, it had been given place to studies that examined the relationship between foreign trade and economic growth. In the second chapter, it has been given place to results by making empirical analysis and in final it has been given place to results and considerations.

\section{Literature Review}

There are a lot of studies that examine the effect of foreign trade on economic growth in the literature. How these studies are done for which countries and years have been listed in below.

Busse and Koniger (2012) had examined the effect of trade on economic growth for 108 countries that 87 of them are developing countries by using annual data in between era of 1971-2005. According to empirical 
analysis result, it had been determined that there are important effects of export and import on GDP.

Saaed and Hussain (2015) had analyzed the effect of export and import on economic growth for Tunisia by using annual data in between era of 1977-2012. Causality relation had been found from growth to import and from export to growth in the result of analysis.

Machado et al. (2014) had searched effect of economic variables on economic growth for BRICS countries by using annual data between 1995-2013. According to empirical analysis results, it had been found that export has positive effects on growth at high volume and investments have negative effects.

Alakbarov (2010) had examined the effect of foreign trade on economic growth for Azerbaijan economy with the help of Johansen cointegration and Granger causality test by using the annual data between 1996-2008 years. While results were revealing that growth hypothesis based on export is not valid, causality had been found from growth to export.

Gül and Kamac1 (2013) had examined the relation of foreign trade and growth for Turkish Republic countries. At the results of analyzes done, while bi-directional causality had been found from export to growth in long term, unidirectional causality relation had been determined from import to growth.

Topallı (2017) had searched the relationship between export and economic growth for 9 chosen countries (Brazil, China, India, Indonesia, South Korea, Philippines, Malesia, Thailand) with the help of panel data analysis by using annual data between 1984-2015 era. According to analysis results, unidirectional causality had been found from export to economic growth in some countries.

Ekanayake (1999) had analyzed the relationship between economic growth and export for 8 developing Asia countries by using annual data in between 1960-1997 era. Research had been analyzed within the scope of Granger Causality Analysis based on two-steps Engle-Granger, Johansen cointegration and error correction model. Application results have shown that there is cointegration relation between export and economic growth in countries subjected to study.

Hatemi-J and Irandoust (2000) had searched the growth hypothesizes based on export for Turkey, Greece, Ireland, Mexico and Portugal. They had applied the Toda and Yamamoto method in the study. While there is not causality relation between export and output for Turkey and Greece in the result of application, it had been found a relation from export to growth for Ireland and Mexico and a relation from growth to export for Portugal.

Zang and Baimbridge (2012) had searched the relation between export, import and economic growth for South Korea and Japan by constituting vector autoregressive model (VAR). According to empirical analysis result, it had been concluded to that there is bi-directional causality on export and economic growth for each country. It had been found that export has negative effect on economic growth in South Korea while export has positive effect on economic growth in Japan.

Kesgingöz, Karamelikli (2015) had analyzed the effect of foreign trade, energy consumption and economic growth on CO2 emission for Turkey by using ARDL bound test for years between 1960-2011. According to test results, the existence of long-term relation had been determined between foreign trade and growth. Foreign trade, energy consumption and economic growth have increased the environmental pollution in long term.

Hameed et al. Had examined the effect of export on economic growth for South Asia countries by using data between 1973-2002. Causality from export to growth had been found in study done.

Omotor (2008) had used the bound test analysis to analyze the long-term relationship between export and economic growth for Nigeria economy. In a consequence of analysis, while export and manpower were affecting the growth positively, rate of exchange and import have affected negatively.

Ajmi et al. Had examined the relationship between export and economic growth for South Africa with the help of Granger Causality test by using data between 1911-2011. As a result of study, they had found bi-directional causality relation between export and growth.

Tang (2006) had examined the growth hypothesis based on export for Hong Kong with the help of ARDL. Bi-directional causality relation had been determined from export to growth as a result of the study.

Al-Yousif (1997) had researched the relationship between export and economic growth for Saudi Arabia, Kuwait, United Arab Emirates, Oman in between era of 1973-1993. According to analysis result, it had been shown that there is a positive and meaningful relation between two variables. 


\section{Analysis}

\subsection{Data Set and Method}

In this study, the effect of foreign trade of 5 countries partaking in Europe Economic Union on economic growth has been examined with the help of panel data analysis by using annual data in between 1992-2015. In the study, reel GDP per person, export and import data had been used as economic growth variable. Variables used in the model had been obtained from World Development Indicators database of World Bank.

\subsubsection{Cross Sectional Dependency}

It had been consulted to Peseran (2004) CDLM test to investigate whether there is cross-sectional dependency or not. The existence of cross-sectional dependency has been checked with Breusch-Pagan (1980) CDLM $_{1}$ test when time dimension is bigger than cross-section size; it has been checked Peseran (2004) CDLM $_{2}$ test when time dimension is equal to the cross-section size and it has been checked with Peseran (2004) CDLM test when time dimension is smaller than cross-section size. These tests have been deviant when group average is different from zero. LM test statistic is at first as follows:

$$
L M=T \sum_{i=1}^{N-1} \sum_{j=i+1}^{N}\left(\hat{\rho}_{i j}^{2}\right) \sim \frac{\chi_{N(N-1)}^{2}}{2}
$$

Peseran et al. (2008) had adjusted this deviation by adding the variance and average to test statistic. For this reason, name has been expressed as corrected $L M$ test $\left(\mathrm{LM}_{\mathrm{adj}}\right)$. $\mathrm{LM}_{\mathrm{adj}}$ statistics is as follows:

$$
L M_{a d j}=\left(\frac{2}{N(N-1)}\right)^{1 / 2} \sum_{i=1}^{N-1} \sum_{j=i+1}^{N} \hat{\rho}_{i j}^{2}\left(\frac{(T-K-1) \hat{\rho}_{i j}-\hat{\mu}_{T i j}}{v_{T i j}}\right) \sim N(0,1)
$$

Null and alternative hypothesizes of cross-sectional dependency test that examine the existence of intersection dependency partaking in the study are as shown below:

$\mathrm{H}_{0}$ : There is no cross-sectional dependency.

$\mathrm{H}_{1}$ : There is cross-sectional dependency.

\subsubsection{Unit Root Test}

Second generation panel unit root tests considering cross-sectional dependency has given information whether which one of them are stable or not for series constituting the panel in contradistinction to first generation panel unit root tests. Unit root pre-hypothesizes are as follows:

$$
\mathrm{H}_{0}: \beta i=0 \text { : Series are not stable. } \mathrm{H}_{1}: \beta i<0 \text { : Series are stable. }
$$

Bootstrap test that is second generation panel unit root testing and is composed of Smith et al. (2004) test statistics which are $\bar{t}, \overline{L M}, \overline{\max }$ and $\overline{\min }$ is going to be applied after the existence of cross-sectional dependency was determined in the analysis step of the study. ${ }^{\bar{t}}$ test is the bootstrap version of the panel unit root test that is incident to Im et al. (2003) and it has been calculated as $\bar{t}=N^{-1} \cdot \sum_{i=1}^{N} t_{i} . \overline{L M}$ test statistic is the average value of personal LM test statistics and it has been calculated as $\overline{L M}=N^{-1} \cdot \sum_{i=1}^{N} L M_{i}$. While $\overline{\max }$ test was developed by Leybourne (1995) and it is calculated as $\overline{\max }=N^{-1} \sum_{i=1}^{N} \max _{i}, \overline{\min }$ statistic is more powerful variance of LM statistics and it is as $\overline{\min }=N^{-1} \cdot \sum_{i=1}^{N} \min _{i}$.

Relevant tests are based on unit root null hypothesis and they have allowed to heterogeneous autoregressive roots under the alternative hypothesis. Therefore, rejection of null hypothesis has pointed out that stability is valid for at least one panel member. 


\subsection{Empirical Analysis Results}

Following equation has shown the functional form of the relation.

$$
G D P=f \text { (export, import) }
$$

The model that is predicted by using panel data analysis method in an attempt to analyze the effect of foreign trade on economic growth for Eurasian Economic Union group countries is as follows:

$$
\operatorname{lngdp_{it}}=\alpha_{i}+\beta_{1} \log \exp _{i t}+\beta_{2} \operatorname{logimp}_{i t}+\varepsilon_{i t}
$$

\subsubsection{Results of Homogeneity and Cross-Sectional Dependency Testing}

Firstly, before passing to causality analysis, it had been investigated whether slope coefficients are homogeneous or heterogenous for each country by way of Pesaran and Yamagata (2008) delta tests.

Table 1. Homogeneity test of Pesaran and Yamagata (2008)

\begin{tabular}{lcc}
\hline & Test Statistic & Probability \\
\hline delta_tilde & 14.175 & $0.000^{* * *}$ \\
delta_tilde_adj & 15.466 & $0.000^{* * *}$ \\
\hline have shown that null hypothesis was rejected at $1 \%, 5 \%$ and $10 \%$ significance level, respectively.
\end{tabular}

According to Table 1, null hypothesis defending that slope coefficients are homogeneous since probability values of delta and corrected delta test statistics are smaller than 0.05 significance level. In other words, slope parameters have changed in between cross sections and they are heterogenous.

Table 2. Results of cross-section dependency test

\begin{tabular}{lllllll}
\hline Fixed Models & GDP Stat. & p-value & exp Stat. & p-value & imp Stat. & p-value \\
\hline $\mathrm{CD}_{\operatorname{lm}}(\mathrm{BP}, 1980)$ & 147.317 & $0.000^{* * *}$ & 33.467 & $0.000^{* * *}$ & 23.576 & $0.009^{* * *}$ \\
$\mathrm{CD}_{\operatorname{lm}}($ Peseran,2004) & 30.705 & $0.000^{* * *}$ & 5.247 & $0.000^{* * *}$ & 3.036 & $0.001^{* * *}$ \\
$\mathrm{CD}$ (Peseran, 2004) & -3.276 & $0.001^{* * *}$ & -2.503 & $0.006^{* * *}$ & -1.605 & $0.054^{* *}$ \\
$\mathrm{LM}_{\text {adj }}$ (PUY, 2008) & 10.865 & $0.000^{* * *}$ & 2.125 & $0.017^{* *}$ & 3.788 & $0.000^{* * *}$ \\
\hline
\end{tabular}

Note. $* * * * * *$ have shown that null hypothesis was rejected at $1 \%, 5 \%$ and $10 \%$ significance level, respectively.

Table 2 has shown the cross-sectional dependency test results of Breusch and Pagan (1980). From Table 2, null hypothesis that specifies that there is no cross-sectional dependency since probability value of $C D_{B P}$ cross-sectional dependency test statistic is smaller than 0.05 significance level for all variables constituting the Model (1) has been rejected. In this case, second generation unit root tests that consider cross-sectional dependency and can be applied for heterogeneous panels at the same time are going to be used while unit root specifications of series were searched.

\subsubsection{Unit Root Test Results}

Panel data analysis that is constituted by gathering the cross-sectional observations in a specific time period have brought time series specifications and problems in its wake. If the existence of unit root was found in data, spurious regression problem has shown up in panel data analysis. Therefore, searching whether series constituting the model have unit root or not have quite mattered in the prediction stage of model.

Table 3 have shown the panel unit root tests results that include constant term of every series constituting the Model (6).

Table 3. Smit et al. "bootstrap" Panel Unit Root Tests

\begin{tabular}{cccccc}
\hline Levels & \multicolumn{2}{c}{ Constant } & \multicolumn{3}{c}{ Constant and trend } \\
\hline & Statistic & Bootstrap p-value & & Statistic & Bootstrap p-value \\
\hline GDP & -0.729 & 0.826 & GDP & -2.995 & 0.054 \\
exp & -0.887 & 0.896 & exp & -2.659 & 0.125 \\
imp & -1.143 & 0.753 & imp & -2.408 & 0.301 \\
& First Differences & & & First Differences & \\
GDP & -3.130 & $0.007^{* * *}$ & GDP & -2.603 & 0.173 \\
exp & -4.107 & $0.000^{* * *}$ & exp & -3.976 & $0.000^{* * *}$ \\
imp & -3.465 & $0.000^{* * *}$ & imp & -3.415 & $0.004^{* * *}$ \\
\hline
\end{tabular}

Note. ***, **, * have shown that null hypothesis was rejected at $1 \%, 5 \%$ and $10 \%$ significance level, respectively. 
Model have included the constant term. Probability values had been derived by 5000 bootstrap loops. Block volume and maximum delay time had been defined as 100 and 4, respectively.

According to finding obtained from Table 3, GDP, exp, imp variables are stable series in their first differences.

\subsubsection{Causality Test Results}

Different methods can be used to determine the causality aspect in panel data. Konya (2006) study has considered both cross-sectional dependency and heterogeneity.

Table 4. Konya panel causality test results

\begin{tabular}{lcc}
\hline & Statistic & p-value \\
\hline GDP=>imp & 17.083 & $0.073^{*}$ \\
imp=>GDP & 24.084 & $0.007^{* * *}$ \\
exp=>GDP & 10.598 & 0.390 \\
GDP=>exp & 22.204 & $0.014^{* * *}$ \\
imp=>exp & 33.452 & $0.000^{* * *}$ \\
exp=>imp & 9.060 & 0.526 \\
\hline
\end{tabular}

Note. $* * * * *, *$ have shown that null hypothesis was rejected at $1 \%, 5 \%$ and $10 \%$ significance level, respectively.

Table 4 has shown that Konya Panel Causality test results. According to results obtained from table, while bi-directional causality was determined from GDP to import, unidirectional causality relation had been determined from GDP to export and from import to export.

\section{Conclusion}

Foreign trade has played a strategical role in economic growths and developments of countries. Countries have invested with the inflow foreign exchange as a result of that they import in the most productive areas and this has enabled to pay their external loans. On the other hand, technology and information transfer have been provided to country as a result of export. At the same time, it has enabled to use the resources more rational by providing foreign trade, production and closing the resource gap, also by creating a market for surplus goods composed in domestic market.

Purpose of this study is to examine the effect of foreign trade on economic growth in countries in Eurasia Economic Union. Study that panel data analysis method was used has comprised the years of 1992-2015. In the study, homogeneity of the slope coefficients had been firstly searched for each country and it had been reached to the conclusion that coefficients are heterogenous. This situation has become more than a issue in terms of that foreign trade shock which comes to one of the countries constituting the panel is going to also affect other countries. Because of this, it can be said that countries that are the subject of the analysis should consider the developments related to the countries that they interacted with while they were determining the foreign trade politics.

Other tests that are used in the study are unit root and causality tests. According to unit root test result, it has been seen that series are not stable at the level but they are stable in the first difference. This situation can be regarded as indicator of that effects of foreign trade shocks that come to the related country economies are not going to go down in a brief time.

While bi-directional causality test was determined from growth to import in the result of panel causality test, unidirectional causality had been found from growth to export. There is a feedback effect between economic growth and exports. Within the scope of the findings, it can be said that export and import are important determinants of economic growth of these countries. For this reason, countries need to increase the value given to import and implement export promoting practices will increase economic growth.

\section{References}

Ajmi, A. N., Aye, G. C., Balcilar, M., \& Gupta, R. (2015). Causality between exports and economic growth in South Africa evidence from linear and nonlinear tests. The Journal of Developing Areas, 49(2), 163-181. https://doi.org/10.1353/jda.2015.0021

Alakbarov, E. (2010). An analysis of foreign trade and economic growth in Azerbaijan. Dokuz Eylül Üniversitesi Sosyal Bilimler Enstitüsü, İzmir.

Al-Yousif, Y. K. (1997). Exports and economic growth: Some empirical evidence from the Arab Gulf countries. 
Applied Economics, 29(6), 693-697. https://doi.org/10.1080/000368497326624

Breusch, T. S., \& Pagan, A. R. (1980). The Lagrange Multiplier test and its application to model specification in econometrics. Review of Economic Studies 47, 239-254. https://doi.org/10.2307/2297111

Busse, M., \& Jens, K. (2012). Trade and economic growth: A re-examination of the empirical evidence. Hamburg Institute of International Economics Research Paper 123, 1-24. https://doi.org/10.2139/ssrn.2009939

Ekanayake, E. M. (1999). Exports and economic growth in Asian developing countries: Cointegration and errorcorrection models. Journal of Economic Development, 24(2).

Grossman, G. M., \& Helpman, E. (1991). Innovation and growth in the global economy. Cambridge, Massachusetts, USA: MIT Press.

Gül, E., Kamacı, A., \& Konya, S. (2013). Dış ticaretin büyüme üzerine etkileri: Türk Cumhuriyetleri ve Türkiye örneği. Akademik Bakış Dergisi, No. 35.

Hameed, A., Chaudhary, M. A., \& Khan, K. Y. (2005). The growth impact of exports in South Asian countries. The Pakistan Development Review, 44(4).

Hatemi, J. A., \& Irandoust, M. (2009). Time-series evidence for balassa's export-les growth hypothesis. Journal of International Trade \& Economic Development, 9(3), 355-365. http://dx.doi.org/10.1080/09638190050086195

Im, K. S., Pesaran, M. H., \& Yongcheol, S. (2003). Testing for Unit Roots in Heterogeneous Panels. Journal of Econometrics, 115, 53-74. https://doi.org/10.1016/S0304-4076(03)00092-7

Kesgingöz, H., \& Karamelikli, H. (2015). Dış ticaret-enerji tüketimi ve ekonomik büyümenin CO2 emisyonu üzerine etkisi. Kastamonu Üniversitesi İktisadi ve İdari Bilimler Dergisi, No. 9.

Konya, L. (2006). Exports and growth: Granger causality analysis on OECD countries with a panel data approach. Economic Modelling, 23, 978-992. https://doi.org/10.1016/j.econmod.2006.04.008

Leybourne, S. (1995). Testing for unit roots using forward and reverse Dickey- Fuller regressions. Oxford Bulletin of Economics and Statistics, 57(4), 559-571. https://doi.org/10.1111/j.1468-0084.1995.tb00040.x

Machado, M. E. R., Paulo, S. C., \& Alexandre, C. (2014). Economic growth and economic variables: An analyze of BRICS. Retrieved from http://www.ppge.ufrgs.br/anpecsul2015/artigo/Economic_growth_and_economic.pdf

Omotor, D. G. (2008). The role of exports in the economic growth of Nigeria, the bounds test analysis. International Journal of Economic Perspectives, 2(4), 222-235.

Pesaran, M. H., \& Yamagata, T. (2008). Testing slope homogeneity in large panels. Journal of Econometrics, 142, 50-93. https://doi.org/10.1016/j.jeconom.2007.05.010

Peseran, H. M. (2004), General diagnostic tests for cross section dependence in panels. Discussion Paper, No. 1240 August, p. 5. https://doi.org/10.17863/CAM.5113

Saaed, A. A. J., \& Majeed, A. H. (2015). Impact of exports and 1mports on economic growth: Evidence from Tunisia. Journal of Emerging Trends in Economics and Management Sciences, 6(1), 13-21.

Smith, V., Leybourne, S., Kim, T. H., \& Newbold, P. (2004). More powerful panel data unitroot tests with an application to mean reversion in real exchange rates. Journal of Applied Econometrics, 19, 147-170. https://doi.org/10.1002/jae.723

Tang, T. C. (2006). Export led growth in Hong Kong empirical evidence from the components of exports. International Journal of Business and Society, 7(1), 30-52.

Topall, N. (2017). İhracat ve ekonomik büyüme arasındaki ilişki: boostrap panel granger nedensellik testi. $V$. Anadolu International Conference in Economics, Eskişehir, Turkey.

Tunçsiper, B., \& Rençber, E. Z. (2017). Dış ticaret ve ekonomik büyüme arasındaki ilişki: Türkiye örneği. International Journal of Social Sciences and Education Research, 3(2). https://doi.org/10.24289/ijsser.270501

Zang, W., \& Baimbridge, M. (2012). Exports, imports and economic growth in South Korea and Japan: A tale of two economies. Applied Economics, 44, 361-372. https://doi.org/10.1080/00036846.2010.508722 


\section{Copyrights}

Copyright for this article is retained by the author(s), with first publication rights granted to the journal.

This is an open-access article distributed under the terms and conditions of the Creative Commons Attribution license (http://creativecommons.org/licenses/by/4.0/). 